\title{
Alternate Funding Sources for the International Atomic Energy Agency
}
CM Toomey
AJ Kurzrok
ET Wyse
JM Swarthout

September 2012

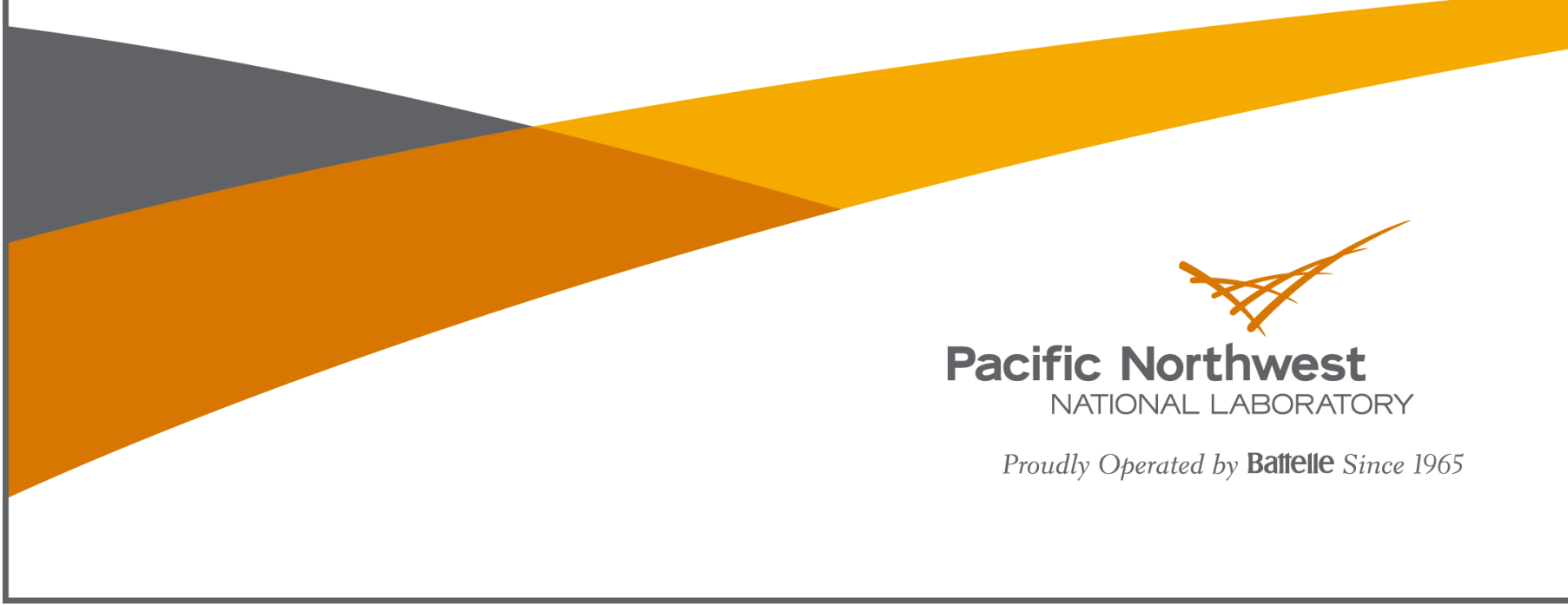




\title{
DISCLAIMER
}

This report was prepared as an account of work sponsored by an agency of the United States Government. Neither the United States Government nor any agency thereof, nor Battelle Memorial Institute, nor any of their employees, makes any warranty, express or implied, or assumes any legal liability or responsibility for the accuracy, completeness, or usefulness of any information, apparatus, product, or process disclosed, or represents that its use would not infringe privately owned rights. Reference herein to any specific commercial product, process, or service by trade name, trademark, manufacturer, or otherwise does not necessarily constitute or imply its endorsement, recommendation, or favoring by the United States Government or any agency thereof, or Battelle Memorial Institute. The views and opinions of authors expressed herein do not necessarily state or reflect those of the United States Government or any agency thereof.

\author{
PACIFIC NORTHWEST NATIONAL LABORATORY \\ operated by \\ BATTELLE \\ for the \\ UNITED STATES DEPARTMENT OF ENERGY \\ under Contract DE-AC05-76RL01830 \\ Printed in the United States of America \\ Available to DOE and DOE contractors from the \\ Office of Scientific and Technical Information, \\ P.O. Box 62, Oak Ridge, TN 37831-0062; \\ ph: (865) 576-8401 \\ fax: $(865) 576-5728$ \\ email: reports@adonis.osti.gov
}

Available to the public from the National Technical Information Service

5301 Shawnee Rd., Alexandria, VA 22312

ph: (800) 553-NTIS (6847)

email: orders@ntis.gov <http://www.ntis.gov/about/form.aspx>

Online ordering: http://www.ntis.gov 


\title{
Alternate Funding Sources for the International Atomic Energy Agency
}

\author{
CM Toomey \\ ET Wyse \\ AJ Kurzrok \\ JM Swarthout
}

September 2012

Prepared for

the U.S. Department of Energy

under Contract DE-AC05-76RL01830

Pacific Northwest National Laboratory

Richland, Washington 99352 



\section{Executive Summary}

Since 1957, the International Atomic Energy Agency (IAEA) has operated at the intersection of the Nuclear Nonproliferation Treaty's (NPT) fourth and third articles, which guarantee Parties to the Treaty the right to peaceful uses of nuclear technology, provided those activities are placed under safeguards verified by the IAEA. However, while the IAEA has enjoyed substantial success and prestige in the international community, there is a concern that its resources are being stretched to a point where it may no longer be possible to execute its multifaceted mission in its entirety. As noted by the Director General in 2008, demographics suggest that every aspect of the IAEA's operations will be in higher demand because of increasing reliance on non-carbon-based energy and the concomitant nonproliferation, safety, and security risks that growth entails. In addition to these nuclear energy concerns, the demand for technical developmental assistance in the fields of food security, resource conservation, and human health is also predicted to increase as the rest of the world develops (IAEA 2008a, p. vii).

Despite the IAEA's 100 percent value-for-money rating from the U.S. Office of Management and Budget, and its label as an "extraordinary bargain" from the United Nations Secretary-General's Highlevel Panel on Threats, Challenges, and Change, budget growth at the Agency has been limited to zero real growth for the better part of the last two decades (IAEA 2008a, p. 24). ${ }^{1}$ As a result, the IAEA continues to defer infrastructure investments, hindering its ability to provide the public goods its Members seek, reducing development opportunities, and decreasing global security. Perhaps more seriously, this situation has transformed the IAEA into a de facto charity, dependent on extrabudgetary contributions to sustain its core mission and capabilities.

To address this concern, the U.S. National Nuclear Security Administration's (NNSA) Next Generation Safeguards Initiative (NGSI) commissioned Pacific Northwest National Laboratory (PNNL) to identify the primary areas of financial concern and develop options to address these needs. From this evaluation, there are three aspects of the IAEA's finances that threaten its future.

First, due to the zero real growth policies in the Regular Budget, the IAEA has been forced to defer investments in its critical infrastructure, which includes the Safeguards Analytical Laboratory (SAL), monitoring equipment at Chernobyl, and the majority of the applied science measurement systems. While the IAEA has been able to assemble a patchwork of voluntary donations for some projects (specifically SAL), most projects remain underfunded and continue to degrade.

Second, the IAEA has no available funds to address crisis situations. The IAEA is the hub of international knowledge and response for any nuclear-related incidents, be they safety, security, or safeguards-related. The current response model appears to require either a redirection of current funds away from day-to-day activities, or an extrabudgetary infusion. Both situations put the IAEA in a difficult situation - that of either jeopardizing core activities due to diversion of funds or being at the mercy of national appropriations processes.

Finally, the IAEA has consistently been unable to meet Member State demand for Technical Cooperation assistance. While funding targets are ostensibly set in accordance with Member State demand, this gap, real or perceived, has consistently been exploited by Member States under the banner

\footnotetext{
${ }^{1}$ Note: there was a one-time increase of 10 percent in 2003 that was phased in over a four-year period, but there has been little to no real-growth in the Agency's budget since.
} 
of NPT Article IV's "right of inalienable access to peaceful nuclear applications." This is to the detriment of the rest of the Regular Budget, where there is a de-facto linkage between growth in Technical Cooperation targets and growth in the safeguards allocation.

To address these issues, the PNNL project team evaluated a number of potential funding mechanisms on their ability to produce sufficient and predictable funds that could be used to resolve these areas of concern. The project team concluded that the best option would be an external endowment, initially funded via the international private and corporate philanthropic market. This endowment would be structured to support the IAEA, while maintaining independence from internal politics. In addition to the endowment concept, the PNNL project team also recommends a series of internal financial reforms that will increase the potential impact of the endowment as well as reduce the political tensions that perennially surround the IAEA's budget process.

It is clear that the IAEA's budget is in need of support. The successful creation of an external endowment could bring some much needed relief to the IAEA's current financial situation, while also stimulating peaceful uses of nuclear technology and innovation in the policy and technology realms, all of which could lead to a more effective and efficient IAEA in the future. 


\section{Acknowledgments}

The authors would like to acknowledge Dr. Trevor Findlay of Harvard University and the Center for International Governance Innovation; Dr. Andy Semmel, head of AKS Consulting; Corey Hinderstein, Vice President of International Programs at the Nuclear Threat Initiative; Dr. Larry Scheinman, Distinguished Professor at the James Martin Center for Nonproliferation Studies; and Matt Brown and Bruce Blair of Global Zero for their thoughtful comments and support. The project team would also like to thank Rizwan Ladha of the Fletcher School and Ben Ford of Pacific Northwest National Laboratory for their contributions to this report. 



\section{Acronyms and Abbreviations}

$\begin{array}{ll}\text { AIPS } & \text { Agency-wide Information System for Programme Support } \\ \text { IAEA } & \text { International Atomic Energy Agency } \\ \text { IEC } & \text { Incident and Emergency Centre } \\ \text { IT } & \text { information technology } \\ \text { MCIF } & \text { major capital investment fund } \\ \text { NGSI } & \text { Next Generation Safeguards Initiative (NNSA) } \\ \text { NNSA } & \text { National Nuclear Security Administration } \\ \text { NPT } & \text { Nuclear Nonproliferation Treaty } \\ \text { NTI } & \text { Nuclear Threat Initiative } \\ \text { OMB } & \text { U.S. Office of Management and Budget } \\ \text { PNNL } & \text { Pacific Northwest National Laboratory } \\ \text { ROI } & \text { return on investment } \\ \text { SAGEM } & \text { Standing Advisory Group for Endowment Management } \\ \text { TC } & \text { Technical Cooperation } \\ \text { WINS } & \text { World Institute for Nuclear Security } \\ \text { ZRG } & \text { zero-real growth }\end{array}$





\section{Contents}

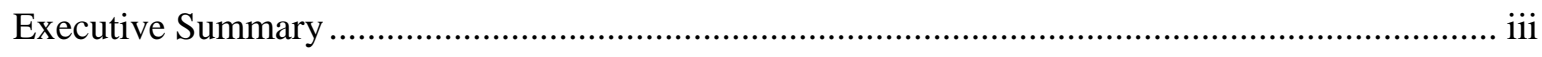

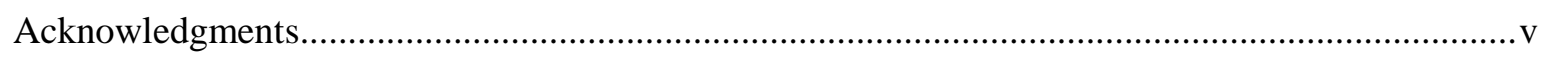

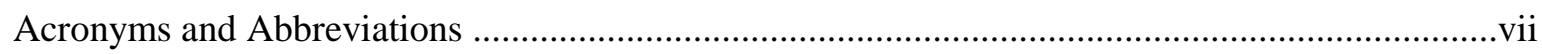

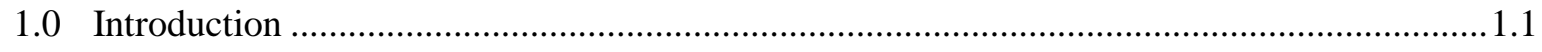

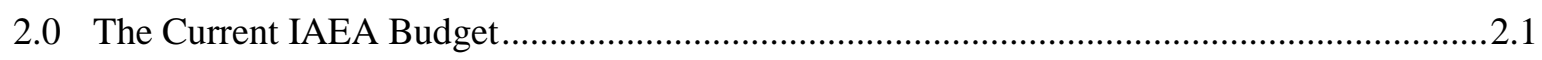

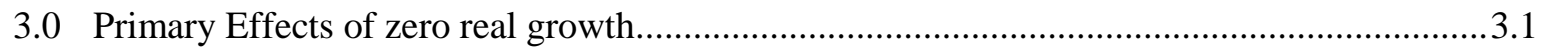

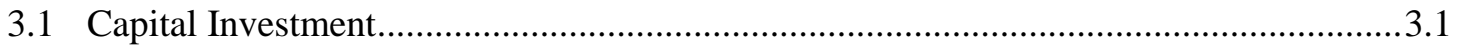

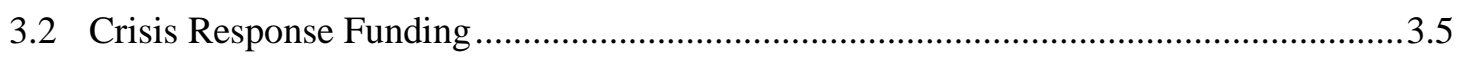

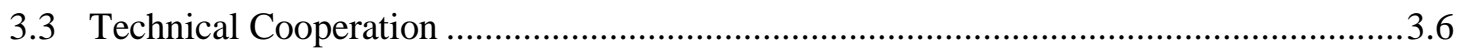

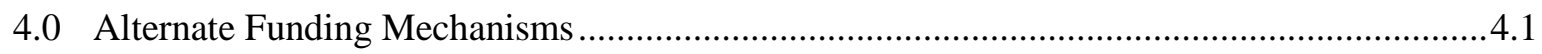

5.0 Structure and Function of an IAEA Endowment.................................................................. 5.1

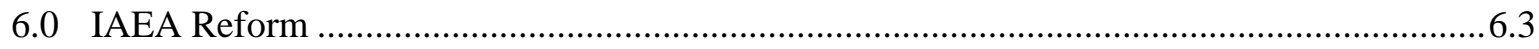

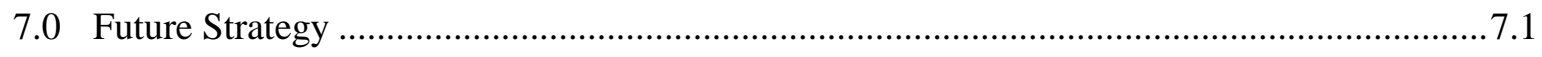

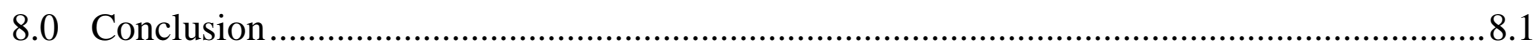

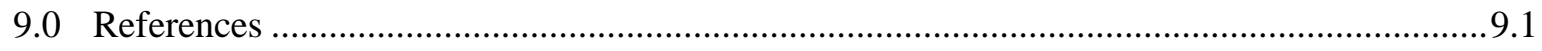




\section{Figures}

Figure 2-1 Share of IAEA Budget by Major Programme

Figure 2-2. Historic Budget of the IAEA..............................................................................2.2

Figure 3-1. Underfunded Projects in Major Capital Investment Fund, 2012 .................................3.3

Figure 3-2. Major Capital Investment Plans, by Budget Year .......................................................

Figure 3-3. Cumulative Major Capital Investment, by Budget Planning Year..............................3.4

Figure 3-4. Technical Cooperation Funding $(2004$ - 2010) ....................................................... 3.7

Figure 5-1. Initial Endowment Performance Assessment ............................................................5.1 


\subsection{Introduction}

Since 1957, the International Atomic Energy Agency (IAEA) has operated at the intersection of the Nuclear Nonproliferation Treaty's (NPT) fourth and third articles, which guarantee Parties to the Treaty the right to peaceful uses of nuclear technology, provided those activities are placed under safeguards verified by the IAEA. However, while the IAEA has enjoyed substantial success and prestige in the international community, there is a concern that its resources are being stretched to a point where it may no longer be possible to fully execute its multifaceted mission. As noted by the Director General in 2008, demographic trends suggest that every aspect of the IAEA's operations will be in higher demand because of increasing reliance on non-carbon-based energy and the concomitant nonproliferation, safety, and security risks that growth entails. In addition to these nuclear energy concerns, the demand for technical developmental assistance in the fields of food security, resource conservation, and human health is also predicted to increase.

It is even less clear in today's uncertain economic environment how these growing demands will be funded. A 2010 study by Toomey et al. at Pacific Northwest National Laboratory (PNNL) concluded that even under the most conservative nuclear energy growth projections, the IAEA would require 5 percent annual budget growth (in real terms) to maintain its status quo safeguards responsibilities (Toomey et al. 2010). As part of the follow-on work to that study, the authors assumed that given the political constraints of the Regular Budget, any growth in safeguards would need to be matched by growth in the rest of the budget, which quickly leads to a clear and significant demand for additional revenue.

Despite the IAEA's 100 percent value-for-money rating from the U.S. Office of Management and Budget, and its label as an "extraordinary bargain" from the United Nations Secretary-General's Highlevel Panel on Threats, Challenges, and Change, budget growth at the Agency has been limited to zero real growth for the better part of the last two decades (IAEA 2008a, p. 24). ${ }^{1}$ As a result, the IAEA continues to defer infrastructure investments, hindering its ability to provide the public goods its Members seek, and decreasing global security and development opportunities. Perhaps more seriously, this situation has transformed the IAEA into a de facto charity, dependent on extrabudgetary contributions to sustain its core mission and capabilities.

Given this context, the U.S. National Nuclear Security Administration's (NNSA) Next Generation Safeguards Initiative (NGSI) commissioned an assessment of potential alternate methods to meet the IAEA's long-term revenue needs. This paper will detail the current state of the IAEA's finances, highlight the primary issues related to IAEA resources, and propose a set of potential solutions for channeling resources to the IAEA, elaborating on one that could enable the IAEA to address many of its fiscal difficulties.

\footnotetext{
${ }^{1}$ Note: there was a one-time increase of 10 percent in 2003 that was phased in over a four-year period, but there has been little to no real-growth in the Agency's budget since.
} 



\subsection{The Current IAEA Budget}

The 2012 IAEA Budget is approximately $\$ 408$ million (IAEA 2011b). ${ }^{1}$ The distribution of funds is shown in Figure 2-1.

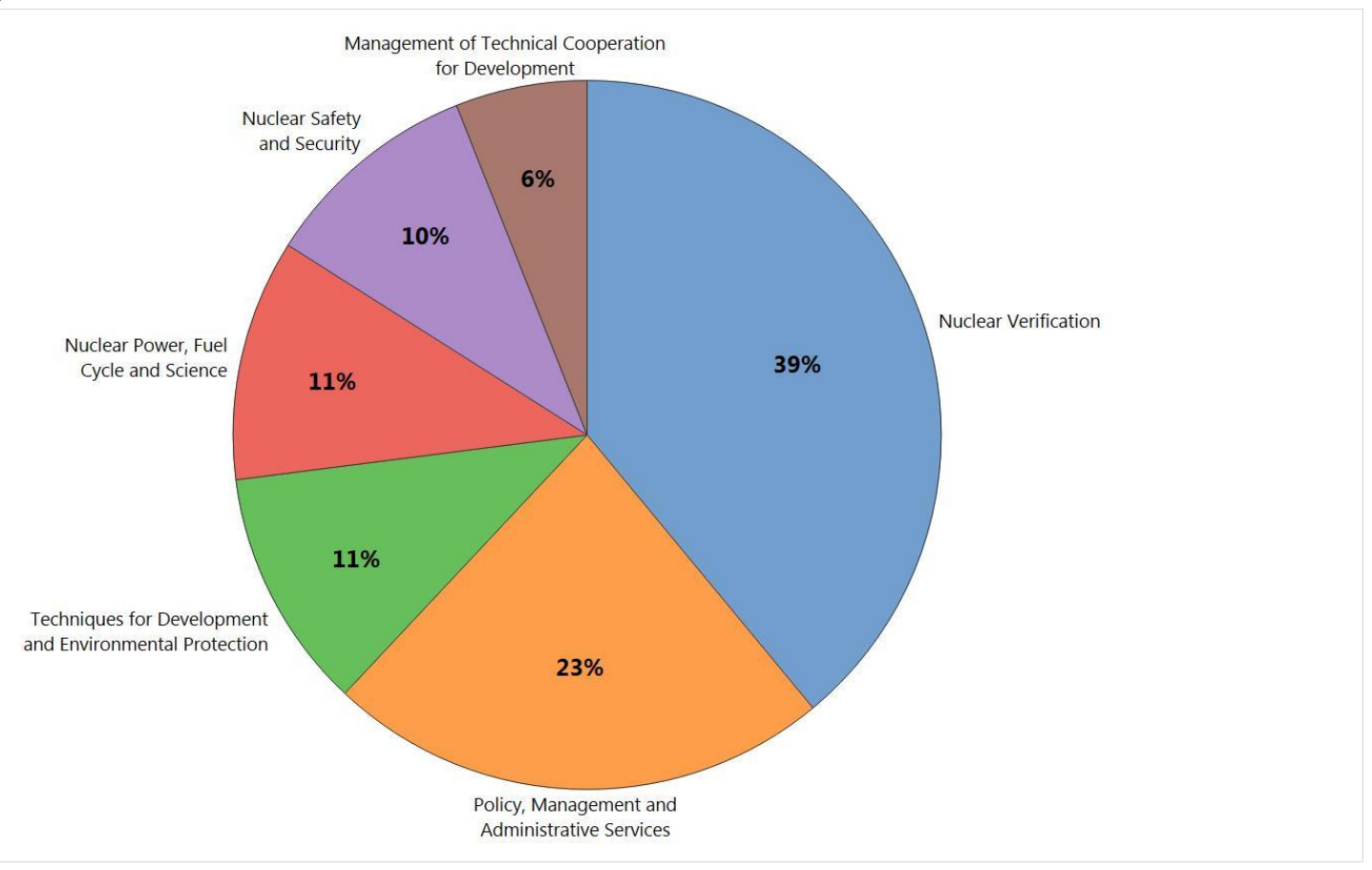

Figure 2-1 Share of IAEA Budget by Major Programme

To put the IAEA Budget in context, $\$ 408$ million is approximately the current procurement cost of a single F-22 Raptor fighter jet (GAO 2011).

Current, growing demands on the IAEA's budget include:

- Safeguards - Increased emphasis on the detection of undeclared facilities and activities under the State-Level Concept.

- Peaceful Uses - Nuclear energy, science and techniques are very much in demand because of the increasing demand for non-carbon energy, scientific infrastructure, human health, and water quality.

- Nuclear Security - Since 9/11, nuclear security has seen an increased emphasis within the IAEA. While security is traditionally a national issue, Member States expect the IAEA to have competency in the core components of security.

- Nuclear Safety - This is an emerging area of emphasis since the Fukushima incident. In addition to the new activities resulting from Fukushima, the IAEA also maintains all the primary Conventions relating to Nuclear Safety, and has a responsibility to set the international standards of behavior for Nuclear Safety.

\footnotetext{
${ }^{1}$ For more background on the Budget, see Appendix A of IAEA 2008.
} 
On the supply side, the IAEA's budget has been subject to a policy of zero real growth for the past few decades.

Figure 2.1 depicts this broad budget challenge. The height of the bars indicates the approved budget, in current dollars, while the color of the bars indicates the real growth, red representing negative growth while black represents positive growth. Since 1982, the Regular Budget has averaged only 1.62\% per year, a stagnation which is visually apparent. In addition, the time scale is compressed to be closer to current day, average real growth converges to near zero.

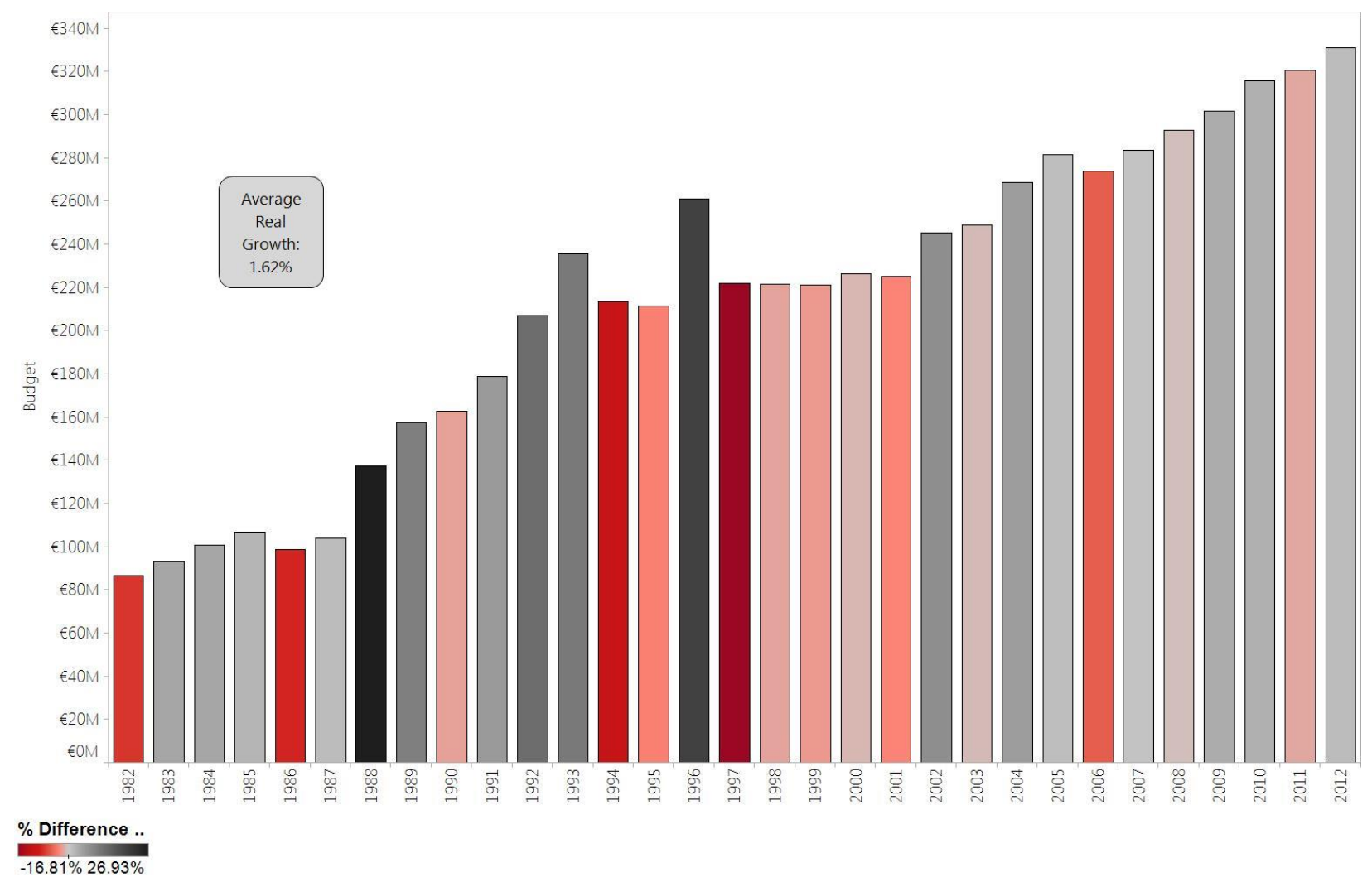

Figure 2-2. Historic Budget of the IAEA

(Growth in Constant 2012 dollars)

(IAEA 1981-1996, 1998-2000, 2001b-2007b, 2008c, 2009b)

An internal policy known as shielding, which was initially designed to protect less-developed countries from potential massive swings in the cost of implementing Comprehensive Safeguards Agreements, exacerbates the zero real growth concern. However, the current financial regulations do not require shielded Member States to pay for any increase in the "safeguards component" beyond inflation. This fiscal de-linking of safeguards from the rest of the Major Programmes (whose consumption by Member States has significant downstream safeguards implications) appears to have created a status quo that, in combination with the constant demand for improvements in effectiveness and efficiency, has made increasing the safeguards budget nearly impossible. A further complication is the the de facto linkage of increases in safeguards funding to increases in Technical Cooperation funding (demand for 
which has been steadily rising) ${ }^{1}$, the resulting stresses placed on the Department of Safeguards are significant. The end result is a growing and possible accelerating unfunded (or at least underfunded) mandate for the Department of Safeguards.

However, while zero real growth is not a sustainable model for the IAEA's Regular Budget, the reforms being undertaken as part of the State-Level Concept and the continuing popularity of the other Major Programmes should result in a more transparent and defensible budget in the near future. When combined with the ongoing emphasis on efficiency throughout the IAEA, particularly in the Department of Safeguards, it is possible that the Regular Budget could be brought back in line with actual and demonstrated needs in the next few years. At present, it is premature to recommend additional external funding mechanisms for the Regular Budget until these impending reforms have been fully implemented.

However, there remain a number of serious resource constraints that must be addressed if the IAEA is to remain scientifically capable and credible. These issue areas, described in the next section, have been exacerbated by zero real growth and do not appear resolvable solely within the political context of the Member State contribution system.

\footnotetext{
${ }^{1}$ For a detailed history and description of the Technical Cooperation-Safeguards linkage, please see Findlay 2012, p.115.
} 



\subsection{Primary Effects of Zero Real Growth}

Beyond the operational concerns of a zero real growth budget, there are three distinct problems areas that, without resolution, could imperil the IAEA's scientific capability and independence over the longterm.

- Capital Investment - Underinvestment resulting from zero real growth has left critical infrastructure, such as the Safeguards Analytical Laboratory, in a severely depreciated state, forcing modernization and maintenance efforts to be funded by voluntary contributions or not at all. This ultimately results in a situation where available funds meet fewer and fewer of the identified needs, and could accelerate capital depreciation.

- Crisis Response - There is presently no dedicated set of funds for use in unanticipated situations where response time is critical. IAEA responsiveness is thus limited to dollars that can be internally reallocated, to the detriment of other activities, or dollars that can be raised through ad hoc voluntary contributions. This results in a situation where the IAEA risks jeopardizing other core activities to respond to an unexpected event.

- Technical Cooperation - The IAEA has been continuously unable to meet Member State demand for Technical Cooperation assistance, falling short of the Technical Cooperation target set by the Board of Governors by an average of $€ 5$ million per year. This intensifies the divisive politics surrounding the IAEA's budget.

\subsection{Capital Investment}

The IAEA owns significant capital stock in the form of the facilities it leases and the scientific equipment it owns. These include, inter alia, the facilities at the Vienna International Centre and the Agency Laboratories in Seibersdorf, an enterprise management system known as the Agency-wide Information System for Programme Support (AIPS), information technology (IT) infrastructure, and advanced scientific instrumentation. Prolonged periods of zero- or near-zero-real growth in the Regular Budget have forced the Agency to defer capital investments as unforeseen safety and safeguards crises have quickly absorbed any surpluses generated by efficiency gains or temporary budget plus-ups. In 2002, the Swiss management consultant Mannet reported that, if continued, this neglect would result in the "dilution of technical knowledge in core organizational competencies" (IAEA 2008a, p. 24).

During the 2008-2009 biennium the Secretariat began to develop a long-term plan of projected major capital investments from 2010-2019. In August 2009, the Board of Governors voted to create a major capital investment fund (MCIF) in order to finance this plan (IAEA 2009b, pp. 47-51). The fund was capitalized by a small transfer from the Regular Budget (which occurs annually) and extrabudgetary donations from Member States. Until the adoption of the MCIF, the IAEA operated primarily on cashbasis budgeting, requiring major boosts in the RB appropriation to cover one-off infrastructure purchases. The MCIF represented a major step towards comprehensive capital budgeting by giving the Agency the means to smooth out RB appropriations and save up for major investment expenditures

Potential investments by the MCIF must meet the IAEA's five-pronged major capital investment criteria:

1. Be a compelling priority. 
2. Have a useful life in excess of one financial period (year).

3. Have a total value throughout their lifespan of $€ 200,000$ or more.

4. Be of a major infrastructure nature, e.g., buildings, major IT backbone systems, and other infrastructure such as the AIPS.

5. Be major expenditures of a one-off or infrequent nature, which would cause significant distortion to levels of the operational portion of the Regular Budgets. Partial tranches/installments could be provided over several years in order to avoid spikes in funding requirements in the Regular Budget in any one period (IAEA 2009b, paragraph 144).

The first major capital investment plan covered the period from 2010-2019. Initial investments included replacing aging equipment at the Agency's laboratories in Seibersdorf and Monaco, updating the Incident and Emergency Centre, equipping new facilities at the Vienna International Centre with furniture and electronics, and improving safeguards analytical capabilities.

While the MCIF is intended to support all infrastructure projects, it is currently underfunded by approximately $€ 28$ million (Figure 3.1). Of that $€ 28$ million, approximately $€ 23$ million is needed for projects critical to the IAEA's ability to carry out its mission, as determined by the IAEA (IAEA 2011b, p.44). It should be noted that as of the printing of the 2012 Budget, the most successful capital fundraising effort, for Seibersdorf, was underfunded by $€ 10.4$ million. This project has recently reached its fundraising target, but the remaining level of need in the MCIF appears to indicate some serious concerns with regards to the IAEA's capital planning and fundraising process. 

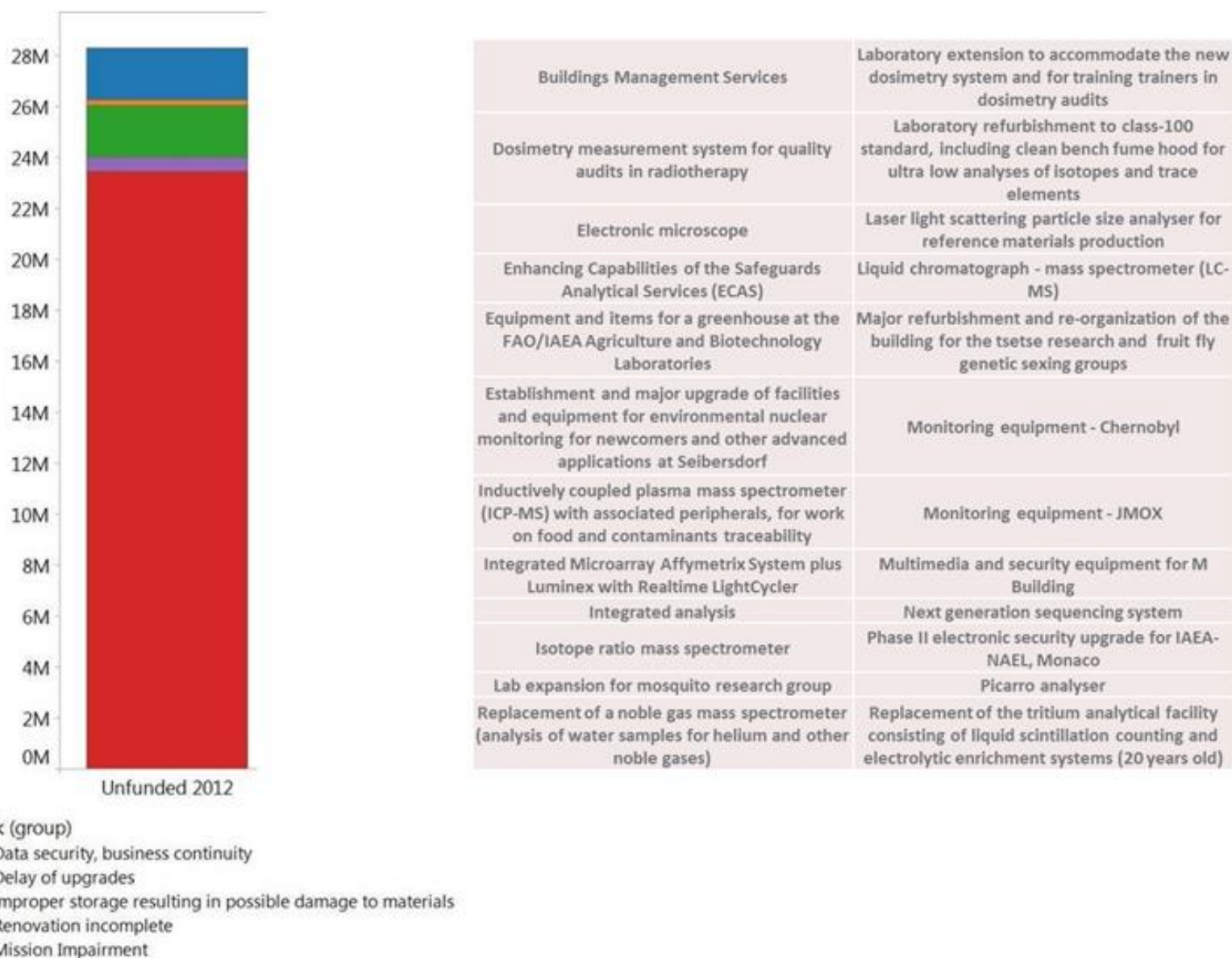

Figure 3-1. Underfunded Projects in Major Capital Investment Fund, 2012

(IAEA 2011b, p.44)

Figures 3.2 and 3.3 display the two versions of the IAEA's most recent capital plans. Figure 3.2 shows the year-by-year Capital Investment needs, while Figure 3.3 shows the cumulative needs by the individual planning years (first planning year, second planning year, etc.). 


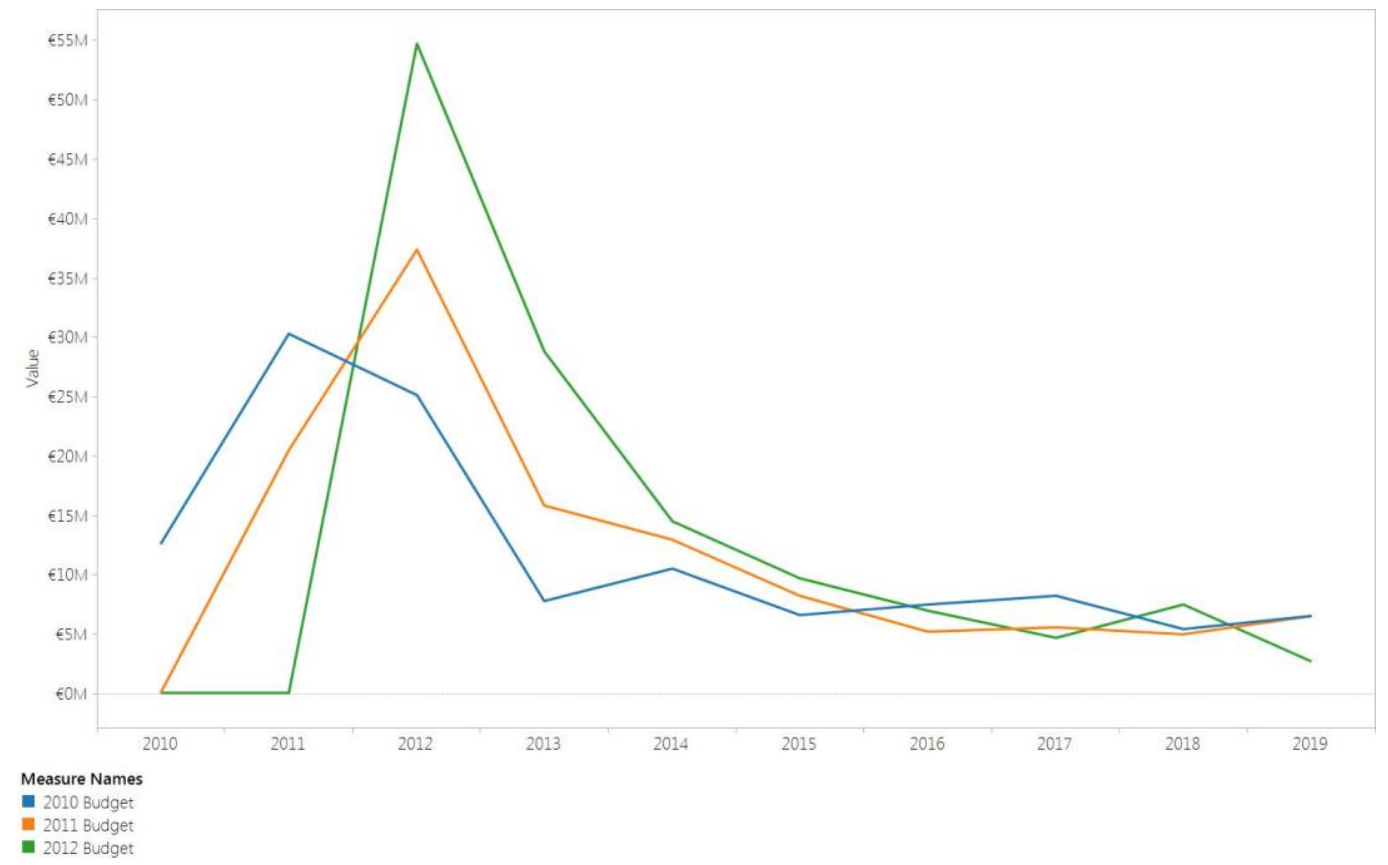

Figure 3-2. Major Capital Investment Plans, by Budget Year

(IAEA 2009b, 2010b, and 2011b)

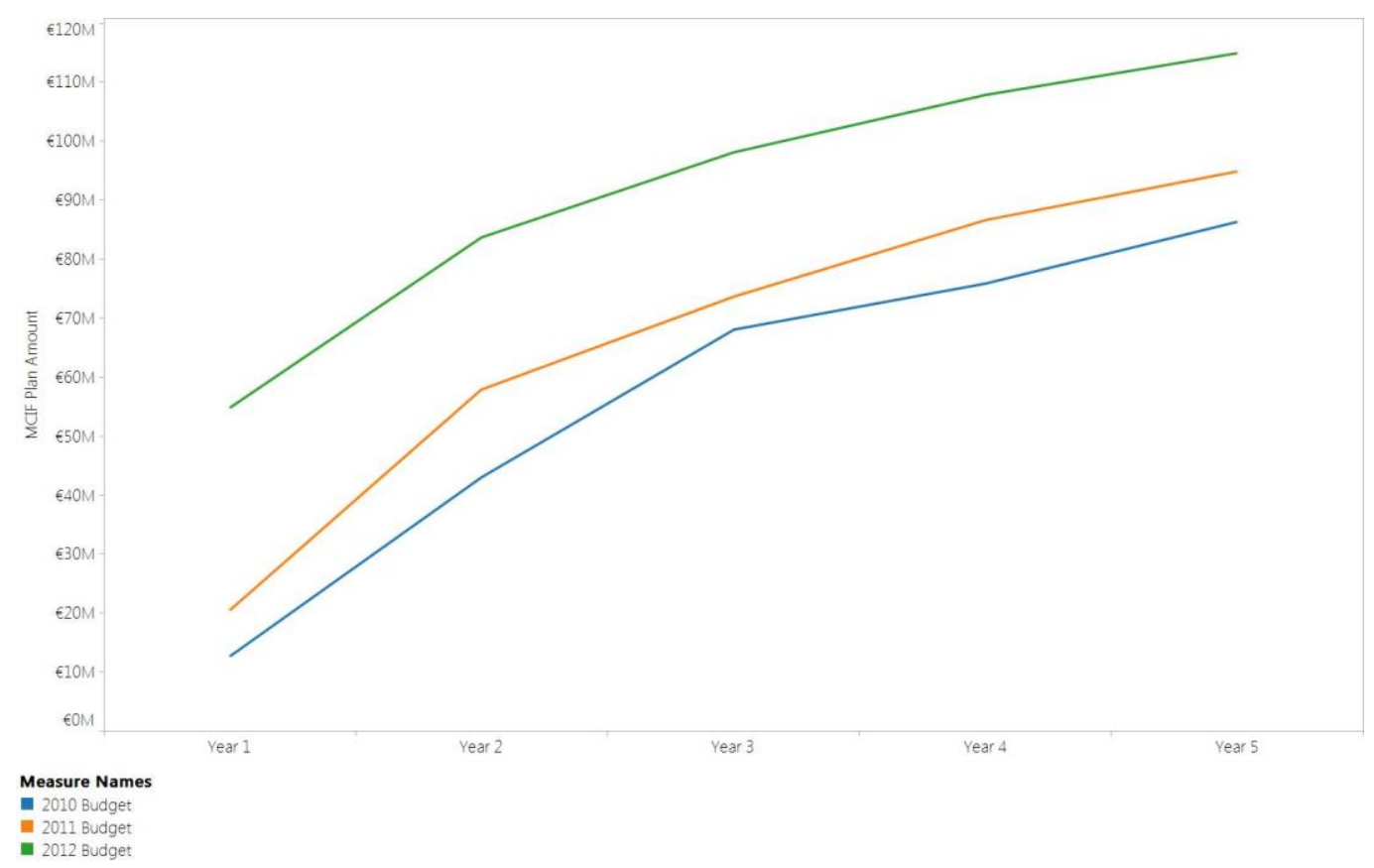

Figure 3-3. Cumulative Major Capital Investment, by Budget Planning Year

(IAEA 2009b, 2010b, and 2011b) 
Taken together, it is clear that the IAEA's needs are increasing and potentially accelerating. For example, in 2010 the IAEA expected that it would require an MCIF budget of approximately $€ 26$ million in 2012, which grew to an approximately $€ 37$ million expectation in 2011 , and actually was approximately a $€ 55$ million request in 2012 . This expansion is likely attributed to the IAEA's inability to plan for infrastructure needs, zero real growth, a cap on guaranteed capital funding infusions from the Regular Budget's working capital fund, and a lack of investment in the MCIF by Member States. The result is a zero real growth-inflicted downward spiral, where the lack of guaranteed funds limits capital investments that can be made in a given year, potentially resulting in capital stock depreciating faster than it can be upgraded, while introducing more competition for funds because of future projects coming up for investment.

\subsection{Crisis Response Funding}

As the sole international organization dedicated to the peaceful uses of nuclear science and technology, Member States depend on the IAEA to provide assistance and expertise in nuclear safety, security, and safeguards. This includes, perhaps most importantly, in times of crisis. Safety, security, and safeguards incidents have all required immediate, complex responses that shifted the focus away from regular operations. An example for each case is provided below:

- Safety: The recent events at Fukushima underscore the Agency's role in a nuclear safety emergency. The IAEA's Incident and Emergency Centre (IEC) was staffed by approximately 200 staff around the clock for 54 days following the accident. Fukushima-related activities consumed all unencumbered funding within Major Programme 3: Safety and Security, which does not include a one-time transfer of $€ 114,000$ from other unspent Major Programme-related funds (IAEA 2012a, p. 84).

- Safeguards: The revelations of previously undeclared activities in the Democratic People's Republic of Korea, Iran, and Syria have forced the Agency to reallocate resources to investigate and bring previously undeclared facilities under safeguards.

- Security: The IEC also has a role to play in nuclear security emergencies. Following the 2007 infiltration of the Pelindaba nuclear facility (Karzis 2010), the IAEA sent a team of experts to assess the situation, and reported that "there was no evidence that sensitive nuclear areas were under any threat at any time during the incident," but recommended several adjustments to training procedures and security equipment (IAEA 2008b). The Agency also plays a role in coordinating significant resources after the report of a lost or found radioactive source, and has been called in to help find missing sources and characterize and secure sources once they are discovered. In one instance, the IEC had an international team en route to Chile within 24 hours after Chilean regulators discovered an unshielded iridium-192 source that had seriously injured a construction worker (IAEA 2012b).

When taken together, unanticipated activities can cause significant stress on the Agency in the form of diverting resources away from Regular Budget activities. The Agency therefore remains dependent on voluntary contributions to fulfill its mission. However, absent sustained voluntary funding, this is a zerosum situation, where funds must be diverted from core activities towards crisis response, which may then limit the completion of a core-mission task. 


\subsection{Technical Cooperation}

The Technical Cooperation Programme can be viewed as the embodiment of the NPT's Article IV requirement, which reads in part (United Nations, Department for Disarmament Affairs 2005):

"[T] facilitate, and have the right to participate in, the fullest possible exchange of equipment, materials and scientific and technological information for the peaceful uses of nuclear energy. Parties to the Treaty in a position to do so shall also co-operate in contributing alone or together with other States or international organizations to the further development of the applications of nuclear energy for peaceful purposes, especially in the territories of non-nuclear-weapon States Party to the Treaty, with due consideration for the needs of the developing areas of the world."

The TC Programme is distinct in that the management of the Programme is funded out of the Regular Budget's Major Programme 6, and the projects themselves are funded out of an Extrabudgetary Fund, the Technical Cooperation Fund (TC Fund).

The IAEA's current strategy is to ensure that TC projects are based on demand from Member States, are relevant to actual needs and development priorities, and are cost effective (IAEA 2002c). All projects are evaluated against the Model Project Standards, which require that all TC projects respond to a real need of the country; produce significant economic or social impact through the end user; reflect the distinct advantage of nuclear technology over other approaches; and attract strong government commitment (IAEA 1997). The goal of these requirements is to move away from the "buffet" model to a needs-based and right-sized approach for development through the peaceful applications of nuclear technology.

However, the IAEA is currently unable to meet the demands of its Members for TC projects. Each year, the Board of Governors sets a TC Fund target to pay for TC projects, to which Member States make pledges to pay, and then pay into at the assessed United Nations rate. Figure 3.4 displays the targets, pledges, and payments from 2004 to 2010. 


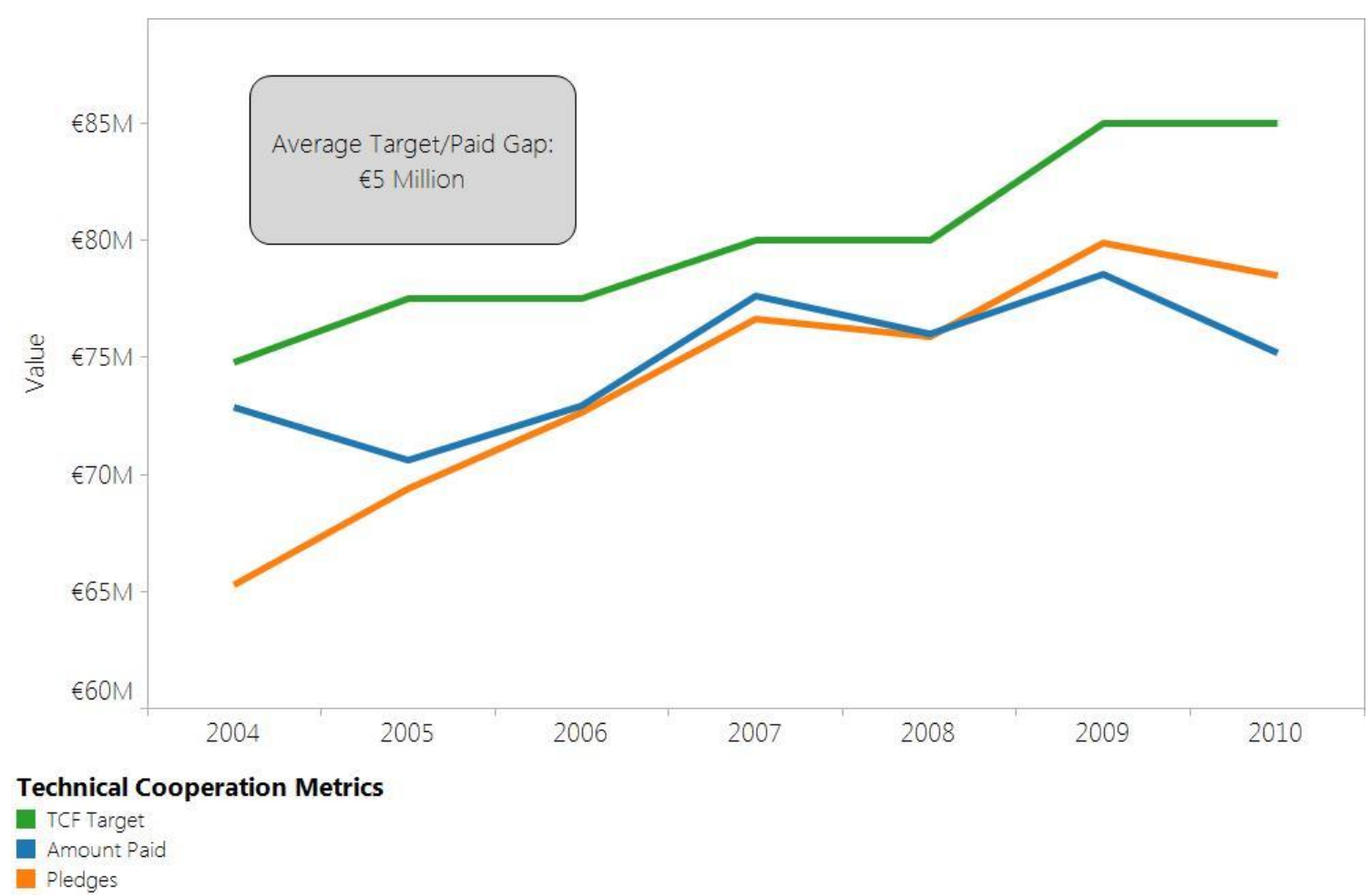

Figure 3-4. Technical Cooperation Funding (2004 - 2010)

(IAEA 2003a-2007a, 2008b, 2009a-2011a)

Figure 3.4 clearly shows that donors consistently miss the TC target by about $€ 5$ million. This indicates that either States are unwilling or unable to pay their fair share (fairness in TC is relative, given the "voluntary" nature of the contributions), Members overstate their need for TC-related development, or the target is set artificially high by the Board (or some combination). Read simply, the consistent gap between TC demand and TC supply implies that the IAEA is not fulfilling its mission under Article IV of the Statute. This shortfall can then be exploited by Member States under the banner of the right of "inalienable" access to peaceful nuclear applications under NPT Article IV. Given that TC is an ostensibly demand-based program, any perceived inability to execute the peaceful uses mission can be used to hamstring the budget process, particularly in safeguards. 



\subsection{Alternate Funding Mechanisms}

In a previous report (Toomey et al. 2011), the project team identified a number of potential alternate funding mechanisms that could generate additional revenues for the IAEA over the long-term, while also resolving the immediate resource issues. These options included:

- endowment

- fee-for-service/fuel cycle facility tax

- charitable donations.

To summarize the previous report, the project team consulted the academic literature of financing of global public goods, specifically in the international development space, to derive a framework that could assist in evaluating each of these options. From this review, the project team established the following requirements:

1. Any system of financing must ensure that the IAEA's mission areas remain equally treated, but not necessarily equally funded. This rule emphasizes the importance of the IAEA's mission, as a whole, rather than as constituent parts. Some may require more resources or attention than others, but all are equally important to the success of the mission.

2. The funding mechanism should be as efficient and fair in its collection scheme as possible. As is their right, the IAEA's Membership values each aspect of the mission differently, and seeks to consume different amounts of the IAEA's services. Any additional funds must preserve the ability of all Members to access IAEA services and programs without affecting the ability of other Members to do so. To ensure this, those with a greater ability to pay should do so.

3. Funding mechanisms must be conducive to the operation of a professional international agency. The goal of the funds is to ensure an effective operation. To support the IAEA effectively, any funding mechanism must be

- Appropriate. The type of funding provided must be able to support the IAEA's diverse mission while not subjecting it to undue economic or political influences.

- Sufficient. Monies must be able to cover most of the planned activities for the year, while also providing a stable pool of funding to cover unanticipated costs/activities.

- Assured. The IAEA must be confident that it will receive a certain level of revenue in a given year.

- Predictable. The amount of revenue for future years should be able to be calculated with some level of certainty, and be able to keep pace with the IAEA's changing needs.

From this assessment, the project team concluded that a charity-driven model could not provide guaranteed supply of sufficient funding to support the IAEA. However, the project team did note that the IAEA could be made more accessible to charitable contributions, as there is no simple way for individuals or organizations to contribute directly to the mission. In addition, the fee-for-service/taxation scheme was discarded because of the political sensitivities surrounding the creation of the fee basis, and the lack of legal authority of the IAEA to tax its Members beyond the current Regular Budget assessment process. 
On paper, a privately funded endowment model could provide sufficient funds to support the IAEA in all of the identified areas. The next section will describe our testing of the notional endowment and describe its structure and function. 


\subsection{Structure and Function of an IAEA Endowment}

In order to test the feasibility of an endowment, the project team constructed a simple financial spreadsheet that provides a model of the endowment against the following criteria: Coverage of demand growth in the IAEA budget (set at 5 per cent nominal growth/year) between now and 2030. ${ }^{1}$ Given that this test imposes demands in excess of those identified in the earlier sections, it follows that if an endowment could provide sufficient funds through return on investment (ROI) to meet broad budget demand growth, it would be sufficient to fund the identified issue areas. The project team assumed that the ROI was static and would perform in line with the observed long-term performance of university endowments (Toomey et al. 2011). The project team also assumed that the IAEA budget would grow at 1 per cent (nominal) per year, and that the fund would begin generating returns in 2014, with pay-outs beginning in 2016. Figure 5.1 displays the endowment's performance against the IAEA budget gap.

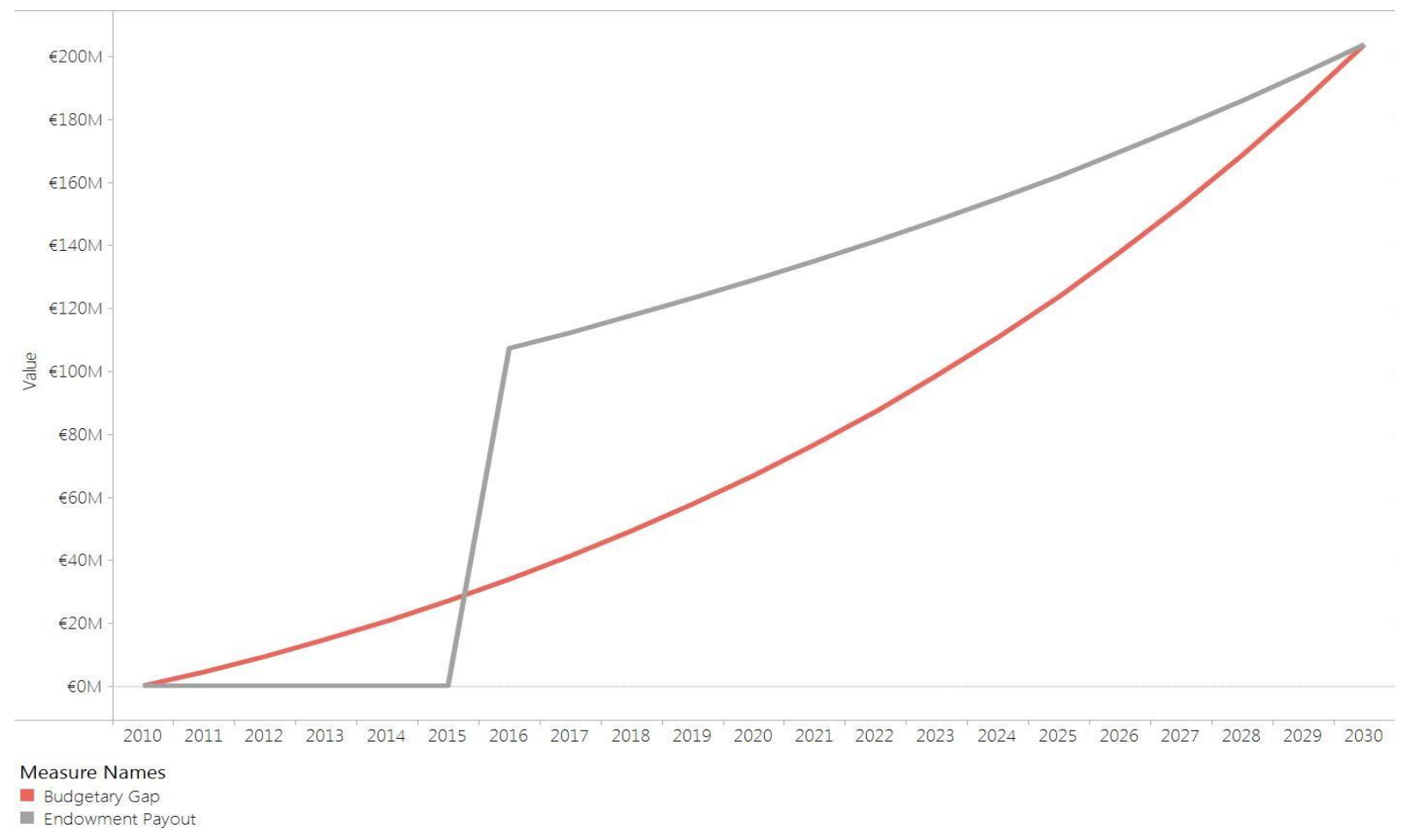

Figure 5-1. Initial Endowment Performance Assessment

From these assumptions, the project team derived an initial principal investment of $€ 2$ billion, equivalent to $\$ 2.47$ billion. While the endowment appears to have the potential to deliver sufficient funds, it is clear from the simplicity of this model (i.e. the lack of fit between our model and the funding needs) that a more sophisticated financial analysis, one that takes into account the stated needs as identified previously, is warranted. As to the actual capitalization of the endowment, the project team, based on an initial literature review, feels that the private and corporate philanthropic market could support such a fund. However, given the complexity of the philanthropic sector, the high level of competition for funds, and the lack of clarity on the necessary size of the principal, this report will not speculate on the ability to raise the necessary funds.

\footnotetext{
${ }^{1}$ This is the estimated amount of growth sufficient to meet budget demands through 2030, established in Toomey et al, 2010.
} 
The endowment itself would be professionally managed and external to the IAEA. This maintains independence from the politics that currently affect the Regular Budget. To connect the fund to the needs of the IAEA, the project team recommends the creation of a new entity: the Standing Advisory Group for Endowment Management (SAGEM). SAGEM would comprise

- professional investment experts

- appointees from each of the IAEA's six Major Programmes, selected by their respective Deputy Director Generals.

- a chairman, selected by the Director General, who is not an employee of the IAEA.

SAGEM's function would be to utilize the expertise of the DDG-appointees and the Chairman to inform the endowment's portfolio risk to deliver necessary ROI while preserving the principal and also devise the yearly grant-making strategy.

The fund itself will comprise the following components, funded either from the principal itself (in the case of Crisis Response) or solely from year-to-year ROI.

- Crisis Response Fund. Equivalent to 10 percent of the principal, kept in liquid form so that it can be drawn upon immediately.

- IAEA Infrastructure Fund. This funding tranche will focus on the capitalization of the MCIF and drive internal innovation and reform. The IAEA cannot make investment decisions without assured funding, so the ultimate goal of this fund would be to to provide full capitalization of the MCIF. Given that the Major Capital Investment Plans operate on a rolling 10-year cycle, the desired endstate would be for the MCIF to be fully funded for its operating year, with deposits being applied to future projects in a rolling fashion. This will ensure sufficient cash-on-hand to initiate and/or continue projects while providing the stability necessary for long-term planning. Ideally, the yearly investment requirement would be no larger than the current capital transfer from the Regular Budget to the MCIF in order to maximize funds available for other uses. Once the Infrastructure Fund helps bring the the MCIF to a sufficiently capitalized level, the Infrastructure Fund will target the improvement of internal IAEA processes by providing grant-style funding for appropriate consultancy reviews and implementation of recommendations for reform, which may include additional infrastructure. This will maximize Regular Budget funding for implementation and keep the IAEA effective and efficient.

- Atoms for Peace Fund. This tranche will be constructed as a project partner for Member States in TC, to maximize availability of the TC Program. The project team envisions a Fund that could either act as a partner to the IAEA, by providing funds to the TCF, or acting as a partner for Member States in planning or executing projects.

- New Frontiers Fund. Given the paucity of long-term investments in policy and technology entrepreneurship for arms control, nonproliferation, and disarmament, this tranche of the fund (which will be the remainder of ROI-funds after the other funds are allocated) will be used to fund competitive grants for any individual or organization that wants to explore innovative policy approaches and/or develop and advanced technologies to push the boundaries of thinking. 


\subsection{IAEA Reform}

While the case for an endowment is compelling, there are a number of internal and external budgetrelated reforms that, if implemented, could increase the effectiveness of the endowment. These reforms include:

1. Immediate elimination of shielding. As discussed above and in the 2011 PNNL report, shielding was developed as a means of protecting Member States from unanticipated costs following the implementation of Comprehensive Safeguards. While an admirable goal, the original justification no longer applies, and the continuation of shielding, and its artificial bifurcation of safeguards and non-safeguards components, only further politicizes the Regular Budget process. According to an analysis by Dr. Trevor Findlay, elimination of shielding would make the budget process fairer, while not significantly increasing the assessed contributions of less-developed countries (Findlay 2012, p. 111).

2. Out-year Payment of Assessed Contributions. One of the primary budgetary concerns for the IAEA, both in the Regular Budget and Technical Cooperation, is late payment. Because of assorted fiscal year timing issues, holdups in the passage of budget legislation, economic difficulties, and political gamesmanship, many Member States do not deliver their assessed contributions on time. In a 2010 audit of the IAEA's finances, the auditor discovered that in 2010, more than $€ 37$ million in assessed contributions were outstanding (Findlay 2012, p. 112). The IAEA and Member State Support Programs should investigate potential mechanisms for ensuring that all operational funds are available at the beginning of the IAEA's fiscal year. An improvement in planning and resource requirement development, through long-term strategy development and activities such as the State Level Concept, should provide a basis for sufficient estimates of budgetary needs well in advance of actual implementation. These needs could then be assessed to Member States one to two budget cycles in advance, which could facilitate the collection of necessary funding, and then be adjusted as necessary as implementation needs warrant.

3. Budgetary Grand Bargain. An idea advanced by Dr. Findlay is to trade full funding of Nuclear Security, as its own Major Programme, for incorporation of TC into the Regular Budget. This would ensure that all core activities would be planned for and funded in the Regular Budget, rather than through a set of extrabudgetary mechanisms. This strategy would effectively put Major Programmes on equal footing and make the demand for services transparent and at the forefront of the budget process. Dr. Findlay's recommendation also includes our recommendation to abolish shielding immediately as part of the grand bargain. Where the project team disagree with Dr. Findlay is in the standardization of each Major Programme's share of the Regular Budget, as this could reduce the impetus for a needs-based assessment and limit the IAEA's ability to deliver services according to demand. The project team supports the notion of an alternate funding formula, one which could be based on the size of the nuclear industry in the general sense, or based on the share of safeguards effort expended in each country (regulatory fee-basis model) for safeguards only, while leaving the other Major Programmes untouched (Findlay 2012, p. 121). 
4. Technical Cooperation Reforms. Even if TC is not brought under the Regular Budget in the short-term, there are still a number of reforms advanced by Dr. Findlay that the project team supports. These include greater transparency, earlier notification and greater detail about proposed projects, project prioritization, metrics on Member State's ability to absorb and sustain the investment following completion, better quality control, and better post-implementation reviews. Dr. Findlay proposes that States be "graduated" from TC, based on their technical capability and development status, in order to prioritize effort in the least developed countries, but this may be counter to the inclusive nature of the IAEA. Instead of "graduation," the project team proposes that advanced Member States be required to provide greater shares of support, through national funding or partnerships with nongovernment organizations or corporate entities. This will have a similar effect as Dr. Findlay's proposal, and could also stimulate ownership of the project within the country while integrating the national public and private sectors (Findlay 2012, p. 90). 


\subsection{Future Strategy}

In order for the work of creating the endowment to begin, there are a number of tasks to be completed. Over the next fiscal year, the goal should be to develop the internal structures and functions of the endowment to a sufficient degree that it would be a successful candidate for an external grant, thus making it an independent entity from its inception.

To accomplish this, the project team recommends a two-phase plan:

\section{Phase 1: Financial Analysis}

a. Financial Analysis. Commission an experienced financial entity to explore the principal demands and life-cycle of the endowment's funding and donation model. This analysis will serve as the basis of the outreach and fundraising campaign.

\section{Phase 2: Organizational Planning}

a. Organizational Construction. Engage an experienced consulting organization to provide best-practices in the development of organizational vision and strategy. Best practices in the development of functional requirements such as staffing, legal issues, and communications will be essential to the long-term success of the endowment.

b. Metrics. Engage a diverse set of grant-making entities to understand how to channel funds into areas of highest potential impact, and evaluate performance. The end goal is to understand how to identify potential projects and key individuals, measure potential impact, measure outcomes, and incentivize innovation.

At time of writing, the project team has consulted a number of external validators on the analysis and recommendations contained in this report. While each emphasized different aspects, all agreed with the IAEA's financial concerns. They also agreed that an external endowment could provide both flexibility for the IAEA over the long-term, while also creating an entity that could create broader awareness of the IAEA's mission, while providing a platform for external stakeholders to contribute directly to that mission. 



\subsection{Conclusion}

It is clear from numerous sources that the IAEA's budget is in need of support. While Member States have the responsibility of supporting the IAEA's daily activities, there are a several areas where additional support is clearly warranted. The successful creation of an endowment could bring some much needed relief to the IAEA's current financial situation while also stimulating peaceful uses of nuclear technology and innovation in the policy and technology realms. The project team must also note that while funding is the essential component to resolving the IAEA's resource issue, there are a number of internal reforms that could also enhance the performance and effect of the endowment, while also simplifying the IAEA's budgetary bureaucracy and potentially mitigating some of the political barriers to budgetary reform. 



\subsection{References}

Findlay T. 2012. Unleashing the Nuclear Watchdog: Strengthening and Reform of the IAEA. Center for International Governance Innovation, Ontario, Canada.

GAO. 2011. Defense Acquisitions: Assessments of Selected Weapon Programs. United States Government Accountability Office, Report to Congressional Committees, GAO-11-233SP, U.S. Government Accountability Office, Washington, D.C.

Hudson Institute Center for Global Prosperity. 2012. The Index of Global Philanthropy and Remittances 2012, Hudson Institute Center for Global Prosperity. Available at http://www.hudson.org/files/publications/2012IndexofGlobalPhilanthropyandRemittancesWeb.pdf.

IAEA. 1981. The Agency's Budget for 1982. GC(25)/646, International Atomic Energy Agency. Available at http://www.iaea.org/About/Policy/GC/GC25/GC25Documents/English/gc25-646 en.pdf

IAEA. 1982. The Agency's Programme for 1983-1988 and Budget for 1983. GC(26)/666, International Atomic Energy Agency. Available at http://www.iaea.org/About/Policy/GC/GC26/GC26Documents/English/gc26-666_en.pdf.

IAEA. 1983. The Agency's Programme Budget for 1984. GC(27)/686, International Atomic Energy Agency. Available at http://www.iaea.org/About/Policy/GC/GC27/GC27Documents/English/gc27686_en.pdf.

IAEA. 1984. The Agency's Programme for 1985-86 and Budget for 1985. GC(28)/715, International Atomic Energy Agency. Available at http://www.iaea.org/About/Policy/GC/GC28/GC28Documents/English/gc28-715 en.pdf

IAEA. 1985. The Agency's Budget for 1986. GC(29)/750, International Atomic Energy Agency. Available at http://www.iaea.org/About/Policy/GC/GC29/GC29Documents/English/gc29-750_en.pdf.

IAEA. 1986. The Agency's Programme and Budget for 1987 and 1988. GC(30)/777, International Atomic Energy Agency. Available at http://www.iaea.org/About/Policy/GC/GC30/GC30Documents/English/gc30-777_en.pdf.

IAEA. 1987. The Agency's Budget for 1988. GC(31)/802, International Atomic Energy Agency. Available at http://www.iaea.org/About/Policy/GC/GC31/GC31Documents/English/gc31-802_en.pdf.

IAEA. 1988. The Agency's Programme and Budget for 1989 and 1990. GC(32)/837, International Atomic Energy Agency. Available at http://www.iaea.org/About/Policy/GC/GC32/GC32Documents/English/gc32-837 en.pdf.

IAEA. 1989. The Agency's Budget for 1990. GC(33)/875, International Atomic Energy Agency. Available at http://www.iaea.org/About/Policy/GC/GC33/GC33Documents/English/gc33-875 en.pdf.

IAEA. 1991. The Agency's Budget for 1992. GC(35)/955, International Atomic Energy Agency. Available at http://www.iaea.org/About/Policy/GC/GC35/GC35Documents/English/gc35-955_en.pdf. 
IAEA. 1994. The Agency's Programme and Budget for 1995 and 1996. GC(38)/5, International Atomic Energy Agency. Available at http://www.iaea.org/About/Policy/GC/GC38/GC38Documents/English/gc38-5_en.pdf.

IAEA. 1996. The Agency's Programme and Budget for 1997 and 1998. GC(40)/10, International Atomic Energy Agency. Available at http://www.iaea.org/About/Policy/GC/GC40/Documents/gc40$\underline{10 . h t m l}$.

IAEA. 1997. Technical Co-operation Strategy. GOV/INF/824, International Atomic Energy Agency.

IAEA. 1998. The Agency's Budget for 1999-2000. GC(42)/7, International Atomic Energy Agency. Available at http://www.iaea.org/About/Policy/GC/GC42/Documents/gc42-7.html.

IAEA. 1999. The Agency's Budget for 2000. GC(43)/6, International Atomic Energy Agency. Available at http://www.iaea.org/About/Policy/GC/GC43/Documents/gc43-6.html.

IAEA. 2000. The Agency's Programme and Budget for 2001. GC(44)/6, International Atomic Energy Agency. Available at http://www.iaea.org/About/Policy/GC/GC44/GC44Documents/English/gc44$\underline{6 \text { en.pdf. }}$

IAEA. 2001. The Agency's Accounts for 2000. GC(45)/7, International Atomic Energy Agency. Available at http://www.iaea.org/About/Policy/GC/GC45/GC45Documents/English/gc45-7 en.pdf.

IAEA. 2001. The Agency's Programme and Budget for 2002-2003. GC(45)/8, International Atomic Energy Agency. Available at http://www.iaea.org/About/Policy/GC/GC45/Documents/Budget/gc45$\underline{\text { 8.html. }}$.

IAEA. 2002. The Agency's Accounts for 2001. GC(46)/6, International Atomic Energy Agency. Available at http://www.iaea.org/About/Policy/GC/GC46/GC46Documents/English/gc46-6_en.pdf.

IAEA. 2002. The Agency's Budget Update for 2003. GC(46)/7, International Atomic Energy Agency. Available at http://www.iaea.org/About/Policy/GC/GC46/GC46Documents/English/gc46-7_en.pdf.

IAEA. 2002. The Technical Cooperation Strategy: the 2002 Review. GOV/INF/2002/8/Mod.1, International Atomic Energy Agency.

IAEA. 2003. The Agency's Accounts for 2002. GC(47)/4, International Atomic Energy Agency. Available at http://www.iaea.org/About/Policy/GC/GC47/GC47Documents/English/gc47-4_en.pdf.

IAEA. 2003. The Agency's Programme and Budget for 2004-2005. GC(47)/3, International Atomic Energy Agency. Available at http://www.iaea.org/About/Policy/GC/GC47/Documents/index.html\#.

IAEA. 2004. The Agency's Accounts for 2003. GC(48)/9, International Atomic Energy Agency. Available at http://www.iaea.org/About/Policy/GC/GC48/GC48Documents/English/gc48-9_en.pdf.

IAEA. 2004. The Agency's Budget Update for 2005. GC(48)/2, International Atomic Energy Agency. Available at http://www.iaea.org/About/Policy/GC/GC48/GC48Documents/English/gc48-2_en.pdf.

IAEA. 2005. The Agency's Accounts for 2004. GC(49)/7, International Atomic Energy Agency. Available at http://www.iaea.org/About/Policy/GC/GC49/GC49Documents/English/gc49-7 en.pdf. 
IAEA. 2005. The Agency's Programme and Budget 2006-2007. GC(49)/2, International Atomic Energy Agency. Available at http://www.iaea.org/About/Policy/GC/GC49/GC49Documents/English/gc492_en.pdf.

IAEA. 2006. The Agency's Accounts for 2005. GC(50)/8, International Atomic Energy Agency. Available at http://www.iaea.org/About/Policy/GC/GC50/GC50Documents/English/gc50-8 en.pdf.

IAEA. 2006. The Agency's Budget Update for 2007. GC(50)/6, International Atomic Energy Agency. Available at http://www.iaea.org/About/Policy/GC/GC50/GC50Documents/English/gc50-6_en.pdf.

IAEA. 2007. The Agency's Accounts for 2006. GC(51)/13, International Atomic Energy Agency. Available at http://www.iaea.org/About/Policy/GC/GC51/GC51Documents/English/gc51-13_en.pdf.

IAEA. 2007. The Agency's Programme and Budget 2008-2009. GC(51)/2, International Atomic Energy Agency. Available at http://www.iaea.org/About/Policy/GC/GC51/GC51Documents/English/gc512_en.pdf.

IAEA. 2008. 20/20 Vision for the Future: Background Report by the Director General for the Commission of Eminent Persons. International Atomic Energy Agency. Available at http://www.iaea.org/newscenter/news/pdf/20-20vision_220208.pdf

IAEA. 2008. The Agency's Accounts for 2007. GC(52)/11, International Atomic Energy Agency. Available at http://www.iaea.org/About/Policy/GC/GC52/GC52Documents/English/gc52-11 en.pdf.

IAEA. 2008. The Agency's Budget Update for 2009. GC(52)/5, International Atomic Energy Agency. Available at http://www.iaea.org/About/Policy/GC/GC52/GC52Documents/English/gc52-5_en.pdf.

IAEA. 2008. "IAEA Experts Complete Visit to Pelindaba Nuclear Facility in South Africa" IAEA Press Releases, January 25, 2008. Accessed November 29, 2011 at http://www.iaea.org/newscenter/pressreleases/2008/prn200802.html.

IAEA. 2009. The Agency's Accounts for 2008. GC(53)/4, International Atomic Energy Agency. Available at http://www.iaea.org/About/Policy/GC/GC53/GC53Documents/English/gc53-4 en.pdf.

IAEA. 2009. The Agency's Programme and Budget 2010-2011. GC(53)/5, International Atomic Energy Agency. Available at http://www.iaea.org/About/Policy/GC/GC53/GC53Documents/English/gc53$\underline{5 \text { en.pdf. }}$

IAEA. 2010. The Agency's Accounts for 2009. GC(54)/3, International Atomic Energy Agency. Available at http://www.iaea.org/About/Policy/GC/GC54/GC54Documents/English/gc54-3_en.pdf.

IAEA. 2010. The Agency's Budget Update for 2011. GC(54)/2, International Atomic Energy Agency. Available at http://www.iaea.org/About/Policy/GC/GC54/GC54Documents/English/gc54-2_en.pdf.

IAEA. 2011. The Agency's Accounts for 2010. GC(55)/4, International Atomic Energy Agency. Available at http://www.iaea.org/About/Policy/GC/GC55/GC55Documents/English/gc55-4 en.pdf.

IAEA. 2011. The Agency's Programme and Budget 2012-2013. GV(55)/5, International Atomic Energy Agency. Available at http://www.iaea.org/About/Policy/GC/GC55/GC55Documents/English/gc55$\underline{5 \text { en.pdf }}$ 
IAEA. 2012. The Agency's Financial Statements for 2011. GC(56)/10, International Atomic Energy Agency. Available at http://www.iaea.org/About/Policy/GC/GC56/GC56Documents/English/gc5610_en.pdf.

IAEA. 2012. "The Incident and Emergency Centre (IEC).” IAEA Fact Sheet. Accessed August 28, 2012 at http://www.iaea.org/Publications/Factsheets/English/iec.pdf.

Karzis M. 2010. "Pelindaba: Finding Anton Gerber." CBS News, 60 Minutes, June 21, 2010. Accessed August 28, 2012 at http://www.cbsnews.com/stories/2008/12/04/60minutes/main4647778.shtml.

Krepon M. 2012. "The Gift of Giving." Arms Control Wonk, March 12, 2012. Accessed August 28, 2012 at http://krepon.armscontrolwonk.com/archive/3388/the-gift-of-giving.

Peace and Security Funders Group. 2011. Peace and Security Grantmaking by U.S. Foundations, 20082009. Peace and Security Funders Group. Available at http://peaceandsecurity.org/415/PSFGreport_Jan2011.pdf.

Toomey C, JR Schweighardt, SK Cooley, and CE Mathews. 2010. The IAEA's Safeguards Budget 2010 2030. PNNL-19660, Pacific Northwest National Laboratory, Richland, Washington. Limited Distribution

Toomey C, ET Wyse, AJ Kurzrok, and BE Ford. 2011. Assessment of Alternate Funding Mechanisms for the IAEA. PNNL-20830, Pacific Northwest National Laboratory, Richland, Washington. Limited Distribution

The Giving Pledge. 2012. Accessed August 28, 2012 at http://givingpledge.org/\#enter.

United Nations, Department for Disarmament Affairs. 2005. "Treaty on the Nonproliferation of Nuclear Weapons." 2005 Review Conference of the Parties to the Treaty on the Non-Proliferation of Nuclear Weapons (NPT). Available at http://www.un.org/en/conf/npt/2005/npttreaty.html. 


\section{Distribution}

No. of

Copies

3 National Nuclear Security Administration 955 L'Enfant Plaza

Washington, D.C 20024

Dunbar Lockwood

John Murphy

David Peranteau
No. of

\section{Copies}

1 Foreign Distribution

1 Elena Thomas

C/O UNVIE

IZD Tower

Wagramerstrasse 17-19

1220 Vienna, Austria

4 Local Distribution

Pacific Northwest National Laboratory

Sarah Frazar

PDF

Jason Shergur

PDF

Kevin Whattam

PDF

Gretchen Hund

PDF 




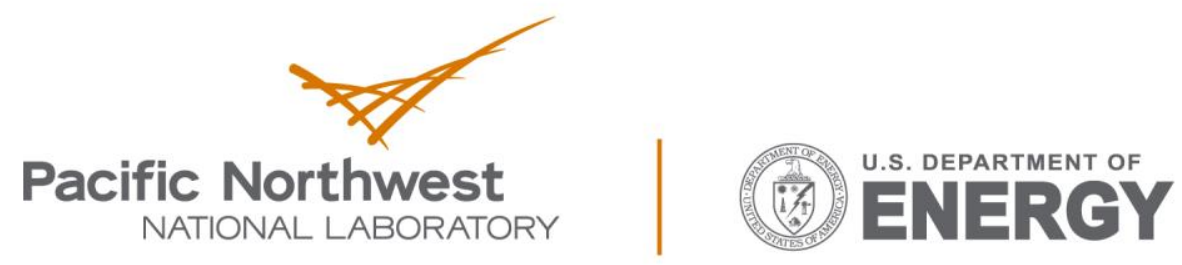

Proudly Operated by Battelle Since 1965

902 Battelle Boulevard

P.O. Box 999

Richland, WA 99352

1-888-375-PNNL (7665)

www.pnnl.gov 